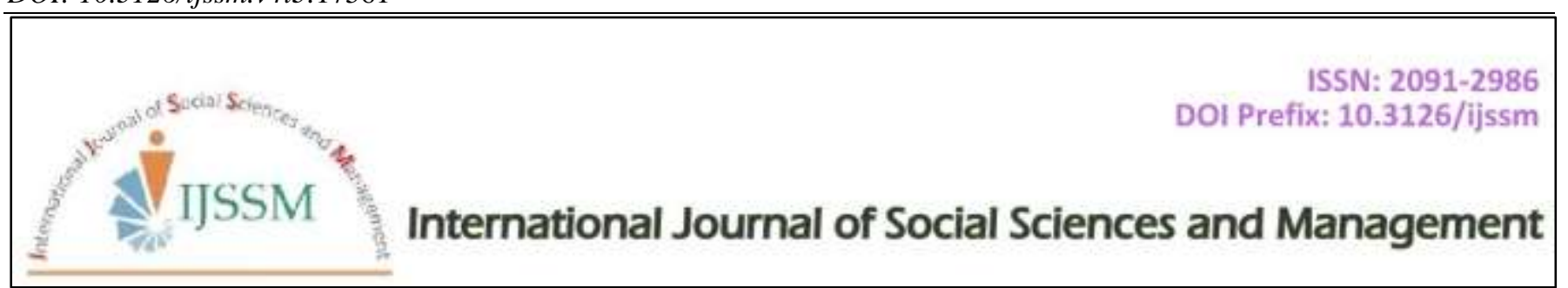

Research Article

\title{
A Study to Assess the Effectiveness of Structured Teaching Programme on Knowledge Regarding Prevention of Anemia among Adolescent Girls in A Selected Senior Secondary Schools of, Bharatpur
}

\author{
Ram Gopal" and Tara Chand \\ Department of Medical Surgical Nursing Shree Digamber College of Nursing Bharatpur India \\ Corresponding author's email: tarachandch@gmail.com
}

\begin{abstract}
Anemia is a condition in which the number of red blood cells or the amount of hemoglobin is low. Red blood cells contain hemoglobin protein that it enables them to carry oxygen from the lungs and deliver it to all parts of the body. A study conducted to assess the effectiveness of structured teaching programme on knowledge regarding prevention of anemia among adolescent girls in a selected senior secondary schools of Bharatpur. During the study, 60 adolescence girls were selected for them pretest is administered for assessing knowledge. After evaluation pretest score was showing lower knowledge regarding prevention of anemia then structured teaching program on knowledge of prevention from anemia administered after one week post test conducted by using same questionnaire this time girls shows increased knowledge regarding prevention of anemia and they are following healthy food habits for the prevention of anemia. Results showing adequate knowledge various methods are used for measuring the variables such as mean, mode, and standard deviation for significance of demographic variables chi square test were used there is no significant demographic variables.
\end{abstract}

Keywords: - Knowledge; prevention of anemia; adolescent girls

\section{Introduction}

Anemia is a condition in which the number of red blood cells or the amount of hemoglobin is low. Red blood cells contain hemoglobin protein that it enables them to carry oxygen from the lungs and deliver it to all parts of the body. When the number of red blood cells is reduced or the amount of hemoglobin in them is low, the blood cannot carry an adequate supply of oxygen. An inadequate supply of oxygen in the tissues produces the symptoms of anemia (Gupta and Kochar, 2009). Adolescence has been defined by the world health organization as the period of life spanning the ages between 10 to 19 years (WHO, 2017). This is the formative period of life when the maximum amount of physical, psychological, and behavioral changes take place. That is a vulnerable period in the human life cycle for the development of nutritional anemia, which has been constantly neglected by public health programmers. During adolescence, (i.e. 10-19 years of age, anemia is estimated to be the greatest nutritional problem. Anemia in adolescents and young adults can have negative effects on their cognitive performance and growth. At all levels, the negative effects of anemia during adolescence justify public health action; unfortunately because initiatives to prevent anemia commonly target infants, young children and pregnant and lactating women, and not necessarily adolescents the needs of adolescents may remain unmet, and the consequences of anemia in adolescents. Iron deficiency anemia is a serious public - health concern in most developing countries. Iron deficiency anemia is estimated to cause 591,000 prenatal deaths and 115,000 maternal deaths globally (Meier et al., 2003). Prevalence of anemia in South Asia is among the highest in the world, mirroring overall high rates of malnutrition (Steven and Abrams, 2008). Anemia remains a major cause of mortality and morbidity in developing countries where resources to determine the underlying etiology remain poor. There are three basic mechanisms for developing anemia, namely: (i) blood loss (hemorrhage); (ii) decreased production of red cells; and (iii) increased destruction of red cells and mortality. Adolescent girls who are potential mothers and 
future homemakers constitute an important part of our society.

\section{Materials and Method}

This chapter deals with description of methodology and different steps, which are under taken for collecting and organizing data for investigation. A Questionnaire (pre experimental one group pre-test post- test) research design was adopted for the study. In the study, the base measure was structured questionnaire to assess the knowledge of adolescent girls regarding prevention \& management of anemia. Research approach is the most significant part of any research. An evaluative research approach was considered the best to assess the knowledge on prevention of anemia among adolescent girls .Variables are characteristics that vary among the subjects being studied. There are two types of variables were identified in this study. They are research variables and demographic variables. Knowledge regarding prevention of anemia It contains baseline characteristic of adolescent girls such as Age, class of study, Religion, Age of menarche Educational status Dietary Pattern. The population of the present study comprises of adolescent girls living at $\mathrm{Sr}$. Sec. School, Bharatpur. The setting refers to the physical location and conditions where data collection takes place. The study was conducted in the selected school, Bharatpur. The setting was chosen on the basis of feasibility in terms of availability of the subjects. Sample is subset of population. The sample size is 60 adolescent girls who were available at the time of data collection and who fulfill the inclusion criteria Sampling technique is an important step in the research process of selecting reprehensive units or subsets of population of the study in a research. Simple random sampling technique was used to select the sample. The investigator selected the samples from selected School, Bharatpur. Pre-testing is the process of measuring the effectiveness of an instrument. Reliability of the tool is the degree of consistency with which it measures the attributes it is supposed to measure. It refers to the extent to which the same result is obtained on repeated administration of the instrument.

In order to establish the reliability of the tool, split-half method was used. The tool was administered to 10 subjects and the test was first divided into two equal halves and correlation of the half test was found by using Karl Pearson correlation coefficient formula and the significance of the correlation was tested by using probable error. The reliability of whole test was estimated by SpearmanBrown's Prophecy formula. The reliability of the structured questionnaire was found to be 0.799 , hence the tool was found to be highly reliable.

\section{Description of the Tool}

The tool consists of two parts:
Part I: the demographic variables had a total of 6 items. It includes regarding Age, class of study, Religion, Age of menarche Educational status Dietary Pattern.

Parts II: Self administered knowledge questionnaire regarding use of the Anemia. It consists of 30 items which were divided into three parts namely:

- General questions regarding blood.

- General knowledge regarding causes, signs and symptoms.

- Knowledge questions regarding treatment and prevention of anaemia.

Each correct answer was given a score of one and the wrong answer was assigned a score of zero. The maximum score for the structured questionnaire was 30 .

The resulting scores were ranged as follows

1. Adequate knowledge-Above $75 \%$

2. Moderately adequate knowledge- $51-75 \%$

3. In adequate knowledge-below- $\leq 50 \%$

\section{Development of STP}

Teaching program is the plan of action of a teacher, which includes the working philosophy of a teacher, his knowledge, information about and understanding of his pupils, his comprehension of the objectives of education, his knowledge of the material to be taught and his ability to utilize effective methods.

\section{Steps involved in the development of STP}

1. Laying out a teaching plan.

2. Preparing an outline of the contents.

3. Deciding methods for instruction.

4. Development of audio- visual aids.

5. Development of criteria check list

6. Content validation of STP

\section{Contents in STP}

- $\quad$ Define anemia

- Incidence of anemia

- causes, signs and symptoms of anemia.

- treatment and prevention of anemia.

Teaching aids: The method of instruction was lecture cum discussion. Aids like L.C.D and hand out, OHP, charts, black board, flash cards.

\section{Pilot Study}

Pilot study is a small version or trial run of the main study. It is conducted to obtain information for improving the main projects or for assessing its feasibility and to test the reliability of the tool. The pilot study conducted at Govt. Sr. Sec. School Utarda Bharatpur, after obtaining the permission from the concerned authorities. The pilot study period was from 20 June of 2016 until 30 June 2016. Totally six adolescent girls were selected in Govt. Sr. Sec. School 
Utarda Bharatpur. Pre-test and Structured teaching Program on Anemia was given on 21 June of 2016 the pre- and the post- test was given on 27 of June 2016. The samples in the study possessed the same characteristics as that of the samples for the main study. The data collected through the questionnaire was analyzed by using descriptive and inferential statistics, which are necessary to provide substantive summary of results. The analyzed data was organized and presented in the form of tables. Tool and STP were found to be effective. The pilot study confirmed that the final study is feasible.

\section{Data collection Process}

A formal permission from the concerned authorities was obtained for conducting the study. Duration of the study was from 1 July 2016 to $27^{\text {th }}$ of July 2016. The investigator took consent from the adolescent girls students. Confidentiality was maintained during data collection.Pretest was done by administering the questionnaire to the samples. An average of six samples was selected. The Structured teaching Program was conducted after pre-test on same day. On seventh day, a post-test was conducted using the same questionnaire to evaluate the effectiveness of structured teaching program. The method of instruction was lecture cum discussion. A.V. Aids like L.C.D and hand out, OHP, charts, black board, flashcards. The time taken for S T P is 45 minutes. The data obtained was analyzed in terms of the objectives and hypothesis of the study by both descriptive and inferential statistics.

\section{Results and Discussion}

\section{Distribution of adolescent girls according to demographic variables}

From the Table 1, it can be deduced that 33.3 percent of the sample [20] were in the age group of 12-13 years, 33.3 percent [20] were in the age group of 14-15 years and 33.3 percent of the sample [20] were in the age group of 16-17. Age of menarche age group is 11-12 years percent of samples is 48.3 percent and the age group 13-14 years percent is 51.7 percent. The religions of the participants have Hindu 6.3 percent and Muslims are having 31.7 percent. The education qualification is those studying in 10th has 31.7 percent, those in 11 th having 43.3 percent and 12 th having 25 percent. The dietary pattern of participants is non vegetarian has 33.3 percent and vegetarian 66.7 percent.

Table 1: Distribution of adolescent girls according to demographic variables.

\begin{tabular}{|c|c|c|c|c|}
\hline S.N. & $\begin{array}{l}\text { Demographic } \\
\text { variables }\end{array}$ & Characters & No. (60) & $\%$ \\
\hline \multirow[t]{4}{*}{1} & \multirow[t]{4}{*}{ Age } & $12-13$ & 20 & 33.3 \\
\hline & & $14-15$ & 20 & 33.3 \\
\hline & & $16-17$ & 20 & 33.3 \\
\hline & & 18-19 & 0 & 0 \\
\hline \multirow[t]{2}{*}{2} & \multirow[t]{2}{*}{ Age of menarche } & $11-12$ & 29 & 48.3 \\
\hline & & $13-14$ & 31 & 51.7 \\
\hline \multirow[t]{2}{*}{3} & \multirow[t]{2}{*}{ Religion } & Hindu & 41 & 68.3 \\
\hline & & Muslim & 19 & 31.7 \\
\hline \multirow[t]{3}{*}{4} & \multirow[t]{3}{*}{ Educational status } & 10th & 19 & 31.7 \\
\hline & & 11th & 26 & 43.3 \\
\hline & & 12th & 15 & 25.0 \\
\hline \multirow[t]{2}{*}{5} & \multirow[t]{2}{*}{ Dietary Pattern } & Non vegetarian & 20 & 33.3 \\
\hline & & vegetarian & 40 & 66.7 \\
\hline
\end{tabular}




\section{Distribution of samples based on age}

It is clear from Fig. 1 that age of adolescent girls divided in to 4 categories (12-13, 14-15, 16-17 \& 18-19 years), equal number was observed in first three categories (20 each) and no any belongs to the age category of $18-19$.

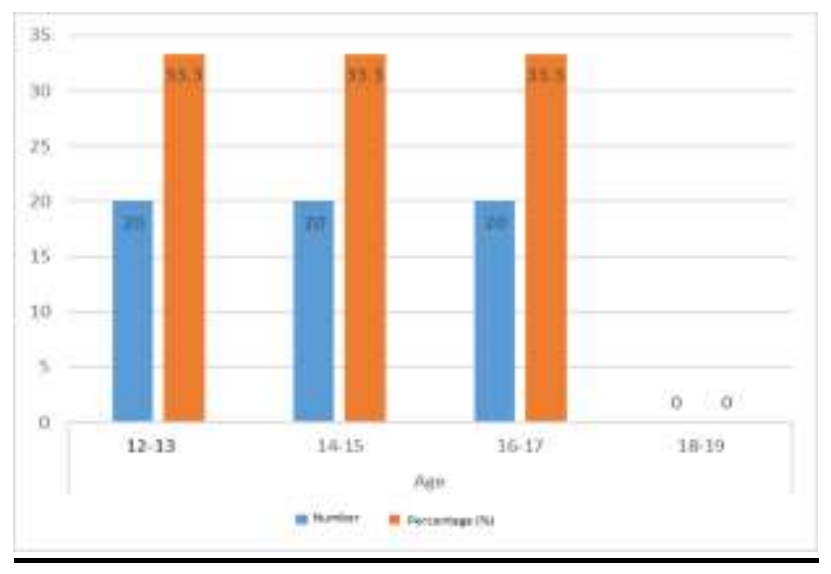

Fig. 1: Age of adolescent girls recorded during study.

\section{Assessment of knowledge on anaemia before STP}

The Fig. 2 shows the level of knowledge were seen into 3 categories, such as- inadequate, moderate and adequate knowledge on anaemia. Majority of adolescent girls i.e., 60 $(100 \%)$ showed inadequate knowledge.

The data presented in Table 2 reveals that the highest pretest mean score is $40.7 \%$ in general information regarding anemia and post-test mean score is $87.0 \%$ in aspect of General information regarding blood. In per test this is followed by Causes, signs and symptoms and treatment and of General information regarding blood with the mean pretest percentage scores $31 \%$ and $30.3 \%$ respectively. But in post-test general information regarding anemia; General information regarding blood; Causes, signs and symptoms and treatment 78.2, 87.0, 82.8 in each aspect. The lowest pre-test mean percentage score is $30.3 \%$ in the aspect of Blood. This is followed by general knowledge on anemia and knowledge on Anemia with the mean pre-test percentage scores $40.7 \%$ and $30.7 \%$ respectively. The lowest post-test mean percentage score is $78.2 \%$ in the aspect of Level of knowledge regarding anemia. This is followed by general knowledge on Anemia (82.8\%) and Blood (87.0\%).

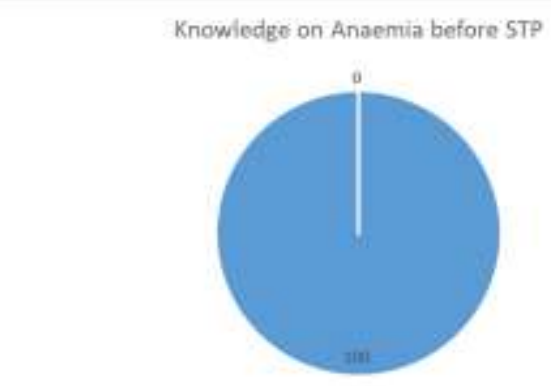

- Inadequate knowledae = Moderate knowledge a Adequate knowieder

Fig. 2: Data showing assessment of knowledge on anaemia before STP.

The 't-value' was computed to determine the effectiveness of STP on Anaemia. The following hypothesis was stated. $\mathrm{H}_{1}$ : There will be significant increase in knowledge of Adolescent girls regarding the Anemia after the STP. The data in Table 3 illustrates that the mean post-test knowledge score [24.78] is higher than the pre-test knowledge score [10.07].The mean difference between pre-test and post-test score [14.71] of knowledge is significant at $\mathrm{P}<0.05$ level, as 't-value' $=59.83$. Hence the research hypothesis $\mathrm{H} 1$ is accepted. The difference of means observed is a true difference. Hence, it can be concluded that the STP has an influence in improving the knowledge of adolescent girls regarding the Anemia.

Table 2: Mean, range and SD of anemia among adolescent girls before and after STP $(n=60)$

\begin{tabular}{|c|c|c|c|c|c|c|c|c|c|c|}
\hline \multirow[t]{2}{*}{ S.N. } & \multirow[t]{2}{*}{ Aspects of knowledge } & \multirow{2}{*}{$\begin{array}{l}\text { Max. } \\
\text { score }\end{array}$} & \multicolumn{4}{|c|}{ Before STP } & \multicolumn{4}{|c|}{ After STP } \\
\hline & & & Range & Mean & SD & $\begin{array}{l}\text { Mean } \\
\%\end{array}$ & Range & Mean & SD & $\begin{array}{l}\text { Mean } \\
\%\end{array}$ \\
\hline 1 & $\begin{array}{l}\text { General information regarding } \\
\text { blood }\end{array}$ & 6 & $0-3$ & 1.82 & 0.74 & 30.3 & $3-6$ & 5.22 & 0.82 & 87.0 \\
\hline 2 & $\begin{array}{l}\text { General information regarding } \\
\text { anemia }\end{array}$ & 7 & $1-4$ & 2.85 & 0.73 & 40.7 & $4-6$ & 5.48 & 0.50 & 78.2 \\
\hline 3 & $\begin{array}{l}\text { Causes, signs and symptoms } \\
\text { and treatment }\end{array}$ & 17 & $1-7$ & 5.40 & 0.97 & 31.7 & $12-16$ & 14.08 & 0.59 & 82.8 \\
\hline 4 & Over all & 30 & $6-13$ & 10.07 & 1.49 & 33.6 & $12-27$ & 24.78 & 1.23 & 82.6 \\
\hline
\end{tabular}


Table 3: Comparison of pre- and post-test knowledge and statistical significance.

\begin{tabular}{|l|l|l|l|l|l|l|}
\hline S.N. & Aspects of knowledge & $\begin{array}{l}\text { Max. } \\
\text { Score }\end{array}$ & $\begin{array}{l}\text { Mean } \\
\text { difference }\end{array}$ & $\begin{array}{l}\text { \% of mean difference } \\
\text { (enhancement })\end{array}$ & $\begin{array}{l}\text { Paired t-test } \\
\text { value }\end{array}$ & $\begin{array}{l}\text { p<value } \\
23.45^{*}\end{array}$ \\
\hline 1 & $\begin{array}{l}\text { General information } \\
\text { regarding blood }\end{array}$ & 6 & 3.40 & 56.7 & $23.11^{*}$ & $\mathrm{p}<0.05$ \\
\hline 2 & $\begin{array}{l}\text { General information } \\
\text { regarding anemia }\end{array}$ & 7 & 2.63 & 37.5 & $49.48^{*}$ & $\mathrm{p}<0.05$ \\
\hline 3 & $\begin{array}{l}\text { Causes,signs and symptoms } \\
\text { and treatment }\end{array}$ & 17 & 8.68 & 51.0 & $59.83^{*}$ & $\mathrm{p}<0.05$ \\
\hline 4 & Over all & 30 & 14.72 & 49.0 & 5 \\
\hline
\end{tabular}

$\mathrm{n}=60$ Note : *-denotes significant at $5 \%$ level $\mathrm{P}<0.05$.

Table 4: Association between demographic variables with knowledge regarding anemia among adolescents girls.

\begin{tabular}{|c|c|c|c|c|c|c|c|c|c|}
\hline \multirow[t]{3}{*}{ S.N. } & \multirow[t]{3}{*}{ Demographic variables } & \multirow[t]{3}{*}{ Characters } & \multicolumn{2}{|c|}{ Sample } & \multicolumn{4}{|c|}{ Knowledge } & \multirow[t]{3}{*}{$\chi^{2 \text {-value }}$} \\
\hline & & & \multirow[t]{2}{*}{ No. (60) } & \multirow[t]{2}{*}{$\%$} & \multicolumn{2}{|c|}{$\leq$ Median } & \multicolumn{2}{|c|}{ >Median } & \\
\hline & & & & & No & $\%$ & No & $\%$ & \\
\hline \multirow[t]{4}{*}{1} & \multirow[t]{4}{*}{ Age } & $12-13$ & 20 & 33.3 & 13 & 35.1 & 7 & 30.4 & \multirow[t]{4}{*}{$0.141, \mathrm{df}=2, \mathrm{NS}$} \\
\hline & & $14-15$ & 20 & 33.3 & 12 & 32.4 & 8 & 34.8 & \\
\hline & & $16-17$ & 20 & 33.3 & 12 & 32.4 & 8 & 34.8 & \\
\hline & & $18-19$ & - & - & - & - & - & - & \\
\hline \multirow[t]{2}{*}{2} & \multirow[t]{2}{*}{ Age of menarche } & $10-12$ & 29 & 48.3 & 17 & 45.9 & 12 & 52.2 & \multirow[t]{2}{*}{$0.220, \mathrm{df}=1, \mathrm{NS}$} \\
\hline & & $13-14$ & 31 & 51.7 & 20 & 54.1 & 11 & 47.8 & \\
\hline \multirow[t]{2}{*}{3} & \multirow[t]{2}{*}{ Religion } & Hindu & 41 & 68.3 & 23 & 62.2 & 18 & 78.3 & \multirow[t]{2}{*}{$1.669, \mathrm{df}=1, \mathrm{NS}$} \\
\hline & & Muslim & 19 & 31.7 & 14 & 37.8 & 5 & 21.7 & \\
\hline \multirow[t]{3}{*}{4} & \multirow[t]{3}{*}{ Educational status } & 10th & 19 & 31.7 & 11 & 29.7 & 8 & 34.8 & \multirow[t]{3}{*}{$1.184, \mathrm{df}=3, \mathrm{NS}$} \\
\hline & & 11th & 26 & 43.3 & 18 & 48.6 & 8 & 34.8 & \\
\hline & & 12th & 15 & 25.0 & 8 & 21.6 & 7 & 30.4 & \\
\hline \multirow[t]{2}{*}{5} & \multirow[t]{2}{*}{ Dietary Pattern } & Non vegetarian & 20 & 33.3 & 12 & 32.4 & 8 & 34.8 & \multirow[t]{2}{*}{$0.035, \mathrm{df}=1, \mathrm{NS}$} \\
\hline & & vegetarian & 40 & 66.7 & 25 & 67.6 & 15 & 65.2 & \\
\hline
\end{tabular}

Note: S-denotes the significant at 5\% level ( $\mathrm{p}<0.05)$; NS- not significant at $5 \%$ level $(\mathrm{p}>0.05)$.

\section{Assessment of effectiveness of STP}

In Table 4, all of the given demographic variables are not significant with the pre-test knowledge.

Age: In 12-13 yrs total no of sample are 20 and the below the median and above 13 and 7,and the degree of freedom is 2 and it is non-significant. In14-15 yrs total no of samples are 20 and the below the median and above 12 and 8, and the degree of freedom is 2. In 16-17 yrs total number of samples are 20 and the below the median and above the median 12 and 8 , and the degree of freedom is 2

Age of menarche: In adolescent girls are 29 number of sample and the below the median and above the median 17 and 12 and degree of freedom is 1 and it is non-significant. In female are 31 number of sample and the below the median and above the median is 20 and 11

Religion: In religion, Hindu 41 number of samples the below the median and above the median is 23 and 18 and the degree of freedom is 1 and non-significant. In Muslims 19 number of samples the below the median and the above the median is 14 and 15 .
Educational status: 10th class student and the number. of samples 19 and the below the median and above the median is 11 and 8 and the school of freedom is 3 and it nonsignificant. 11 th class student is 26 and the below the median and above the median is 18 and 8 and the school of freedom is 3 and it non-significant. $12^{\text {th }}$ class students 15 and the below the median and above the median is 8 and 7 and the school of freedom is 3 and it non-significant.

Dietary pattern: There are 20 number of samples are nonvegetarian and the below the median and above the median is 12 and 8 and the degree of freedom is 1 and it nonsignificant. There are 40 no of samples are vegetarian and the below the median and above the median is 25 and 15 and the school of freedom is 1 and it non-significant.

\section{References}

Gupta N and Kochar G (2009) Pervasiveness of anaemia in adolescent girls of the lower socio-economic groups of the district of Kurukshetra (Haryana). The internet journal of nutrition and wellness 7(1): 1-5. 
Meier PR, Nickerson HJ, Olson KA, Berg RL and Meyer JA (2003) Prevention of iron deficiency anemia in adolescent and adult pregnancies. Clinical medicine \& research 1(1): 29-36.

Steven A. Abrams MD. (2008) Iron requirements and iron deficiency in adolescents. Retrieved from: http://www.uptodate.com/contents/iron-requirementsand-iron-deficiency-in-adolescents

WHO (World Health Organization) (2017) Adolescents: health risks and solutions. Retrieved from: http://www.who.int/mediacentre/factsheets/fs345/en/ 